\title{
Picturing the Divine Agents of Food Bestowal: The Seven Buddhas in the Sweet-Dew Painting of the Chosǒn Period, 1392-1910
}

\author{
Taylor Pak*
}

\section{Introduction}

II. The Assemblage of Buddhas in the Sweet-Dew Painting

III. The Mantras of Invoking the Names of Buddhas Prescribed in the Buddhist Texts on Food-Bestowal Practices

IV. The Sweet-Dew King among the Seven Buddhas

V. Conclusion

\section{Introduction}

The Sweet-Dew painting (Kamnodo 甘露圖) emerged in sixteenth-century Korea to introduce an unprecedented pictorial representation of a group of Buddhas, whose functional significance lie in the “food bestowal” practice (shishik 施食) peculiar to Chosŏn Buddhist liturgy. Notwithstanding the obvious discrepancies in their compositional arrangements, several Buddhas constitute an assemblage, predominantly assuming visual ascendancy over the other Buddhist deities in the upper register of this

* Lecturer, School of Humanities \& Social Sciences, Korea Advanced Institute of Science and Technology (KAIST) 
new painting genre of the Chosonn period (1392-1910). ${ }^{1}$ In the soteriological method of food bestowal, they are indeed the pivotal figures who collectively assume the role of a liturgical agent, exercising divine faculties indispensable for a successful execution of the rites which ultimately enable departed spirits to achieve rebirth in paradise. The presence of an assemblage of Buddhas in the Sweet-Dew painting thus perspicuously manifests its functional link to the modus operandi of salvation via the consumption of a mystically transformed salvific substance, the “sweet dew” (Kr. kamno 甘露; Skt. amrta).

Considering the ritual application of the Sweet-Dew painting, Korean scholars have most notably attempted to construe its portrayals of the assemblage of Buddhas, with reference to canonical and extracanonical texts which expound the liturgical instructions on the rites involving the food bestowal. Initially, Hong Yunsik and Kim Sŭng-hŭi identified the assemblage as the Seven Buddhas (ch'iryorrae 七如來 or Seven Tathāgatas), whose invocations are prescribed in the Yuqie jiyao jiu Anan tuoluoni yankou guiyi jing 瑜伽集要救阿難陀羅尼焰口軌儀經（The Essentials of Yoga Teachings on the Dhāranī FlamingMouth Rite for Saving Ānanda) (T. 1318), one of the esoteric scriptures set forth the observance of the food bestowal to hungry ghosts (Kr. agwi 餓鬼; Skt. preta), and the ritual manual for the performance of the kubyorng shishik 救病施食 (Healing through the Bestowal of Food) included in the Food-Bestowal chapter (shishik p'yŏn 施食編) of Sŏngmun ŭibŏm 䆁門儀範（Manuals for Buddhist Rituals), a compendium of Korean Buddhist liturgies compiled by An Chinho in 1935. However, underlining the incompatibility of their appellations between the two texts, Pak Unkyŏng further considered a corpus of food-bestowal-related texts that potentially have served as the grounds for the genre's espousal of the

1 The upper register of the Sweet-Dew painting also frequently includes the Amitābha triad (Amitābha attended by Avalokiteśvara and Mahasthamaprapta, or Kșitigarbha replacing the latter), a set of two bodhisattvas, Avalokiteśvara and Kșitigarbha, the Bodhisattva Guide of Souls (Illowang posal 引路王菩薩), and heavenly beings. Nevertheless, the assemblage of Buddhas is the only iconographic component that invariably appears in the extant specimens of the Sweet-Dew painting from the Chosonn period, apart from the Bodhisattva Guide of Souls who takes less visual prominence.

2 Hong Yunsik, Han'guk purhwa ǔi yon'gu 韓國佛畫의 研究 (Iri: Wǒn'gwang taehakkyo ch'ulp’anbu, 1980), 185-188; Kim Sŭnghǔi, “Chosǒn shidae Kamnodo ǔi tosang yǒn'gu” 朝鮮時代 甘露圖手 圖像研究, Misulsahakyŏn'gu 196 (December 1992): 24-25, table 2; idem, “Kamnot'aeng ǔi tosang kwa shinang ǔirye” 甘露幀의 圖像诿 信仰 儀禮 in Kamnot'aeng 甘露幀, $2^{\text {nd }}$ ed., ed. Kang Upang and Kim Sŭnghǔi (Sǒul: Yegyǒng, 2010), 456, table 2. Both authors do not specify the latter source, but the Food-Bestowal chapter of Sŏngmun ǔibŏm includes two different sets of the invocation of Buddhas (ch'inyang sŏngho 稱量聖號), the Five Buddhas and the Seven Buddhas for the kwanŭm shishik 觀音施食 (Avalokiteśvara Food Bestowal) and the kubyŏng shishik 救病施食 (Healing through the Bestowal of Food), respectively. See An Chinho, ed., Sŏngmun üibŏm 釋門儀範 (Kyŏngsǒng: Mansanghoe, 1935; Sŏul: Pǒmnyunsa, 2001), 475, 494-495. Citations refer to the Pŏmnyunsa edition. 
Seven Buddhas and additionally the Five Buddhas (oyŏrae 五如來 or Five Tathāgatas), a variant formation also found in the Sweet-Dew painting, albeit only on rare occasions. ${ }^{3}$ Pak conclusively explicated that the Seven Buddhas appertain to those specified in the sixteenth- and seventeenth-century manuals of the Water-Land (suryuk üimun 水陸儀文), advocating the argument previously proposed by Yun Ǔhǔi. ${ }^{4}$ In the most recent study on this issue, Pak Jŏngwŏn also adopted a similar standpoint. ${ }^{5}$ This explanation consequently supported on its merits the general understanding in art-historical scholarship that the iconographies and the ritual function of the Sweet-Dew painting are primarily related to the Water-Land Ritual (Suryukchae 水陸齋). ${ }^{6}$ Meanwhile, however, Chŏng Myŏnghŭi advanced a divergent outlook on the nature of the texts formerly recognized as the Water-Land manuals. ${ }^{7}$ Taking a more inclusive approach, Chŏng regarded the textual sources for the Five and the Seven Buddhas to have embodied the belief in the deliverance of departed spirits, and she contended that the amalgamation of various Buddhist deities in the upper register of the Sweet-Dew painting attests the genre's association to different Buddhist liturgies which entail the food bestowal.

In this article I take a particular stance that the Seven Buddhas portrayed in the Sweet-Dew painting are distinctively linked to their liturgical functions stipulated in the Chosonn redactions of the FoodBestowal manuals (shishik üimun 施食儀文), whose circulations are contemporaneous with the

3 Pak Ǔnkyŏng, Chosŏn chŏngi purhwa yŏn'gu 조선 전기 불화 연구 (Sŏul: Shigongat' ǔ, 2008), 366-367, table 3-13. For a general discussion of the textual basis of the Buddhas depicted in the Sweet-Dew painting, see Hattori Yoshio, "Chōsen lichō butsuga “shoki kanrotei” no sekai: Ōtsu shi Seikyōji shozō Urabonkyō setsusō o yomu” 朝鮮李朝仏画〈初期甘露幀〉の世界: 大津市西敎寺所藏《孟蘭盆経説相》を読む, Ajia yūgaku 29 (2001): 104-108.

4 See Yun Ǔnhǔi, "Kamnowangdo tosang ŭi hyŏngsŏng munje wa 16, 17 segi Kamnowangdo yŏn'gu: Suryukchae ǔigwejip kwa kwallyŏn hayo” 甘露王圖 圖像의 形成 문제와 16, 17세기 甘露王圖 研究: 水陸齋 儀軌集과 관련하여 (Master's thesis, Tongguk University, 2003), 72-73.

5 Pak Chǒngwǒn, “Chosǒn shidae Kamnodo yǒn'gu” 조선시대 감로도 연구 (PhD diss., Tongguk University, 2020), 49.

6 For example, see Kang Pyŏntong and Yi Sŭnghŭi, "Sŏnamsa muhwagi Kamnot'aeng kwa suryuk ǔishingmun ǔi yŏn'gwansǒng koch'al” 仙㦑寺 無畫記 甘露幀과 水陸儀式文의 연관성 古察, Chohyŏng nonch'ong 11 (January 2007): 3-16; Yŏn Cheyǒng, “Ǔiryejǒk kwanjǒm esǒ Kamnot'aenghwa wa Suryuk'wa ǔi naeyong pigyo” 儀禮的 관점에서 甘露幀畫와 水陸畫의 內容 비교, Pulgyohak yŏn'gu 16 (April 2007): 265-297; Pak Ǔnkyŏng, "Ilbon sojae Chosŏn 16 segi suryuk'oe purhwa, Kamnot'aeng” 일본 소재 조선 16세기 수륙회 불화, 감로탱, in Chosǒn shidae Kamnot’aeng: Kamno 朝鮮時代 甘露幀: 甘露(Yangsan: T'ongdosa sǒngbo pangmulgwan, 2005), 1:255-300. Pak Chŏngwǒn particularly advocates the title “Suryuk'oedo" (Water-Land Assembly) based on the viewpoint that the Sweet-Dew painting illustrates the actual event of the Water-Land Ritual. Pak, “Chosǒn chǒngi suryuk'oedo yǒn'gu” 朝鮮前期 水陸會圖 研究, Misulsahakyŏn'gu 270 (June 2011): 35-65.

7 Chǒng Myǒnghǔi, “Chosǒn shidae pulgyo ǔishik ǔi samdan ǔirye wa purhwa yǒn'gu” 朝鮮時代 佛敎儀式의 三壇儀禮终 佛畫研究 (PhD diss., Hongik University, 2013), 158-160. 
emergence of the genre in the sixteenth century. In undertaking the examination of the textual premise of the Seven Buddhas I seek to understand the liturgical inclusivity of the Sweet-Dew painting that occurred by virtue of its creation as the altarpiece for the low altar (hadan 下壇 or yŏngdan 靈壇, “spirit altar”) within the standardized ritual configuration of Chosǒn Buddhism.

The article is divided into three sections. In the first section I analyze the pictorial configurations of the Buddhas manifested in the extant specimens of the Sweet-Dew painting from the Choson period. ${ }^{8}$ This endeavor identifies individual representations of the Five and the Seven Buddhas, especially the latter in different measures of dispositions. Precisely establishing the grounds for further investigation of the Seven Buddhas, the second section elucidates their common function as divine agents in the execution of the rites involving the bestowal of food to departed spirits. It chiefly determines the textual basis on which the Sweet-Dew painting has espoused the Seven Buddhas, by examining the specifications of the mantra invocations prescribed in different Buddhist texts related to the praxis of food bestowal. In further elaborating on the issue of textual association, the section three highlights the potential presence of the Sweet-Dew King (Kamnowang 甘露王) among the Seven Buddhas through particularizing his attributes evinced in the Sweet-Dew painting.

\section{The Assemblage of Buddhas in the Sweet-Dew Painting}

The Sweet-Dew painting conveys either of two different configurations of Buddhas in the upper portion of the picture plane (Table 1). One specimen that atypically exhibits both instances is the SweetDew painting (Ssanggyesa Kamnodo 雙溪寺甘露圖, 1728) housed in the Ssanggyesa Museum (Fig. 1). Set against a mountainous backdrop, independent groups of the Five and the Seven Buddhas are juxtaposed among other Buddhist deities amid floating clouds. Of these two assemblages, the one

8 This article is a revised and expanded version of part of the fourth chapter of my dissertation conducted based on the seventy-four extant Sweet-Dew paintings from the Chosón period. See Taylor Pak, "Shaping the Economy of Salvation: The Gamno Paintings of the Joseon period (1392-1910)" (PhD diss., Seoul National University, 2018), 231-239, appendix 1. The list includes four underdrawings.

9 Hereafter, an English translation of the title is followed by parentheses that contain the romanization of the Korean title under which each individual painting is commonly known in modern scholarship and the date of its production. 


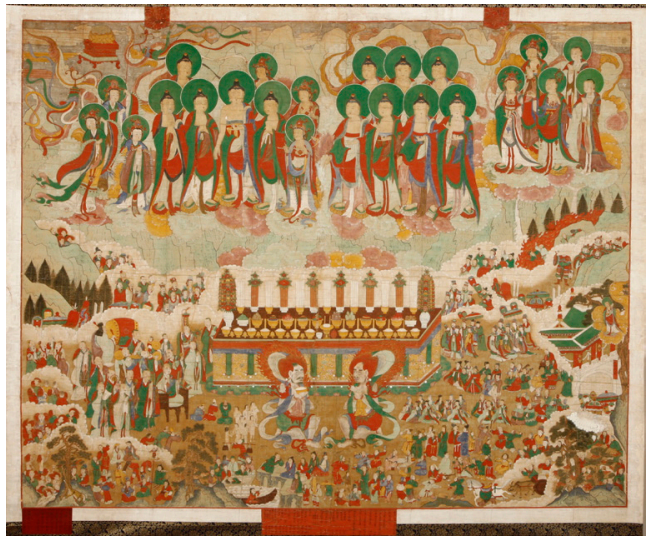

Fig. 1. Sweet-Dew Painting (Ssanggyesa Kamnodo 雙溪寺 甘露圖), 1728 , ink and color on silk, $224.0 \times 281.5 \mathrm{~cm}$, Ssanggyesa Museum (After Kang Upang and Kim Sŭnghŭi, Kamnot'aeng, Fig. 9)

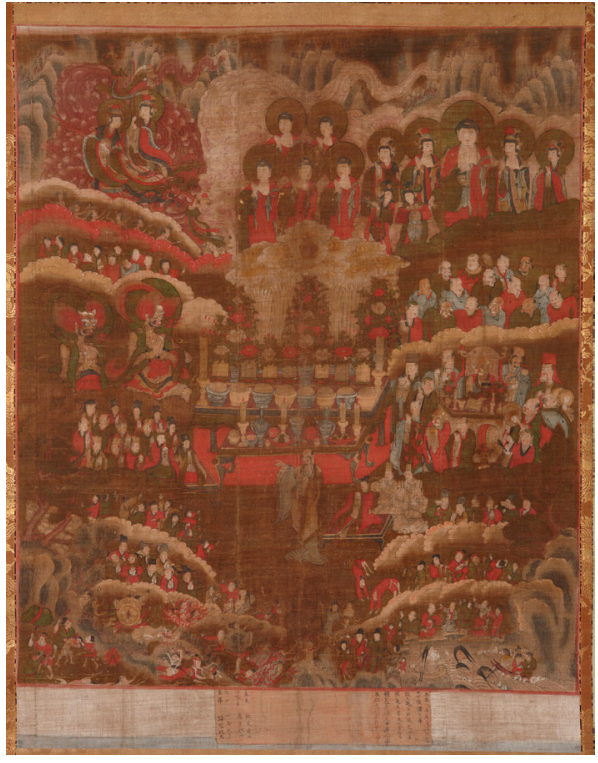

Fig. 2. Sweet-Dew Painting (Kamnodo 甘露圖), 1580, ink and color on hemp cloth, $128.0 \times 111.0 \mathrm{~cm}$, Private Collection (Curtesy of Chŏn Yunsu)

comprising the Five Buddhas is first seen in the Sweet-Dew painting (Kamnodo 甘露圖) dated to 1580 (Fig. 2). It depicts a single group of the Five Buddhas immediately above the elaborate altar offerings. This particular form, however, occurred only on limited occasions thereafter. Merely two other specimens show similar representations from the entire extant corpus of seventy-four Sweet-Dew paintings assigned to the Chosón period: ${ }^{10}$ one housed in the Wŏlchŏngsa 月精寺 Museum (Yŏngwŏnsa Kamnodo 領願寺 甘露圖, 1759) and another in a private collection (Kamnodo 甘露圖, $18^{\text {th }}$ cent.) (Fig. 3). ${ }^{11}$

Apart from these three cases, all specimens of the Sweet-Dew painting deploy the Seven Buddhas in two different modes of formation. First, on most occasions the Seven Buddhas are assembled unequivocally into a single group featuring their central presence. For example, the early works include

10 See note 8 above.

11 The two paintings exceptionally share a near-identical iconographic composition. Such degree of compatibility is quite unusual, since the surviving examples tend to show a high degree of individuality, only with the exception of the nineteenth-century works from the areas of Sǒul and Kyǒnggi Province. Further research may be required to evaluate their association. For the latter painting, see Myŏngin auction, The $2^{\text {nd }}$ Myŏngin Auction Sale (June 2017): 74-75, fig. 78. 


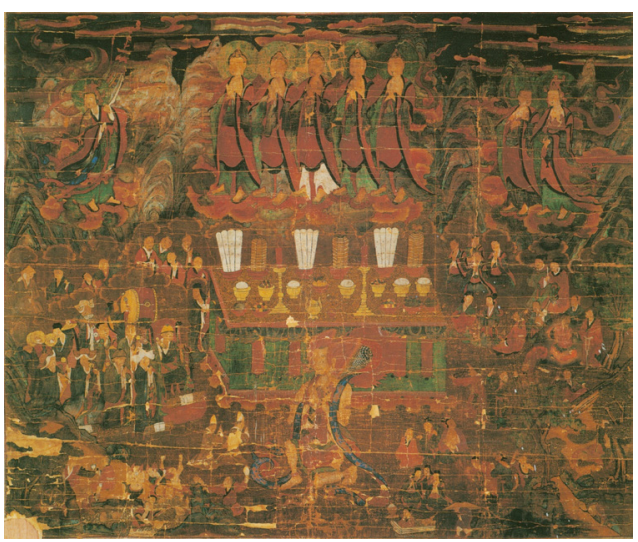

Fig. 3. Sweet-Dew Painting (Yõngwŏnsa Kamnodo 領願寺 甘露圖), 1759, ink and color on silk, $138.0 \times 165.0 \mathrm{~cm}$, Wǒlchŏngsa Museum (After Sŏngbo munhwajae yǒn'guwŏn, Han'guk ǔi purhwa, vol. 10, Fig. 31) the Kōmyō-ji Sweet-Dew painting (Kōmyō-ji Kamnodo 光明寺 甘露圖, $16^{\text {th }}$ cent.) in which the Seven Buddhas are depicted flanked by the Amitābha triad and the Bodhisattva Guide of Souls (Illowang posal 引路王菩薩) (Fig. 4). Moreover, in the case of the Posóksa Sweet-Dew painting (Posŏksa Kamnodo 寶石寺 甘露圖, 1649), the Seven Buddhas dominate the upper portion of the picture plane attended by two bodhisattvas, and on one side is the Bodhisattva Guide of Souls (Fig. 5). Accordingly, similar visual setups of a single composition of the Seven Buddhas prevailed steadfastly throughout the Chosŏn period, with only rare exceptions. Although limited to a few cases, the sixteenth- and seventeenthcentury works, in particular, also adopted variant dispositions. Among the eleven specimens dating from

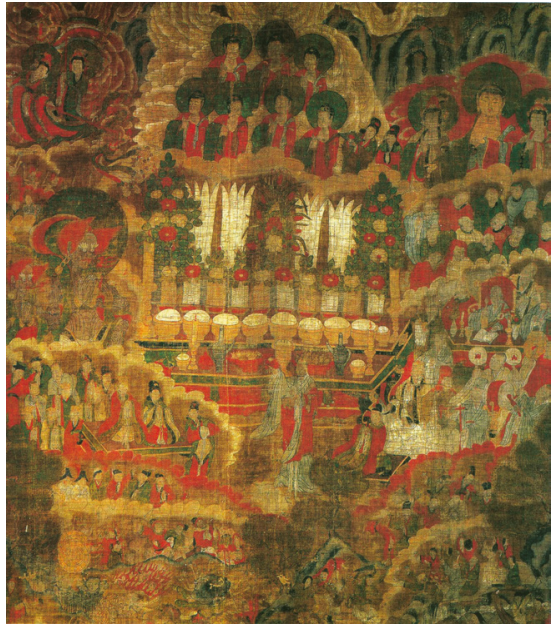

Fig. 4. Sweet-Dew Painting (Kōmyō-ji Kamnodo 光明寺 甘露圖), $16^{\text {th }}$ century, ink and color on hemp cloth, $129.0 \times 123.6$ cm, Kōmyō-ji, Hyōgo Prefecture, Japan (After Kang Upang and Kim Sŭng-hŭi, Kamnot'aeng, Fig. 46)

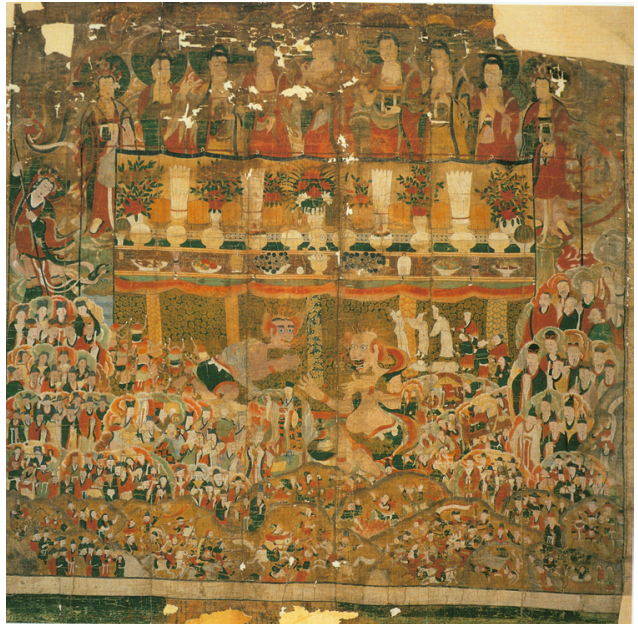

Fig. 5. Sweet-Dew Painting (Posǒksa Kamnodo 寶石寺 甘露圖), 1649, ink and color on hemp cloth, 238.0× 228.0 cm, National Museum of Korea (After Kang Upang and Kim Sŭng-hǔi, Kamnot'aeng, Fig. 3) 


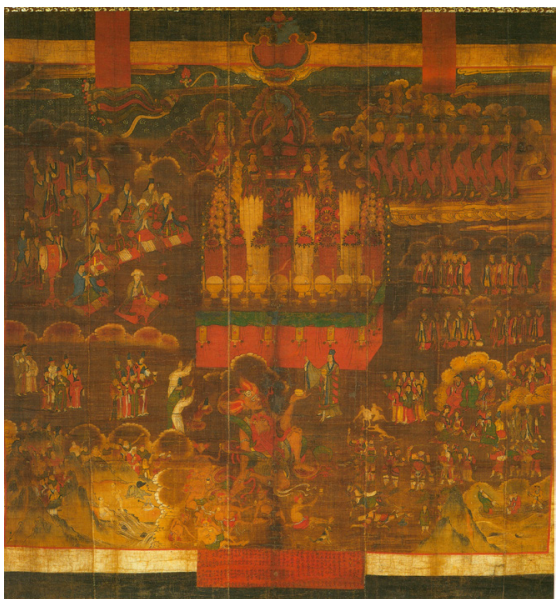

Fig. 6. Sweet-Dew Painting (Yakusen-ji Kamnodo 藥仙寺 甘露圖), 1589, ink and color on hemp cloth, $158.0 \times 169.0 \mathrm{~cm}$, Nara National Museum (After Kang Upang and Kim Sŭng-hŭi, Kamnot'aeng, Fig. 1)

these periods, three arrange the Seven Buddhas in the manners that they visually subordinate to the Amitābha triad. The SweetDew paintings in the collections of Yakusen-ji (Yakusen-ji Kamnodo 藥仙寺 甘露圖, 1589) and Ch'ŏngnyongsa (Ch'öngnyongsa Kamnodo 靑龍寺 甘露圖, 1692) portray the Seven Buddhas on the far right of the centrally stationed Amitābha triad (Figs. 6 and 7), and another in Saikyō-ji (Saikyō-ji

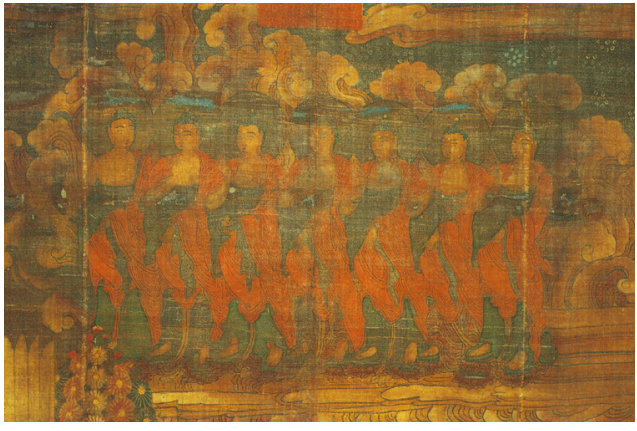

Fig. 6-1. Detail of the Seven Buddhas (After Kang Upang and Kim Sŭng-hŭi, Kamnot'aeng, Fig. 1-3)

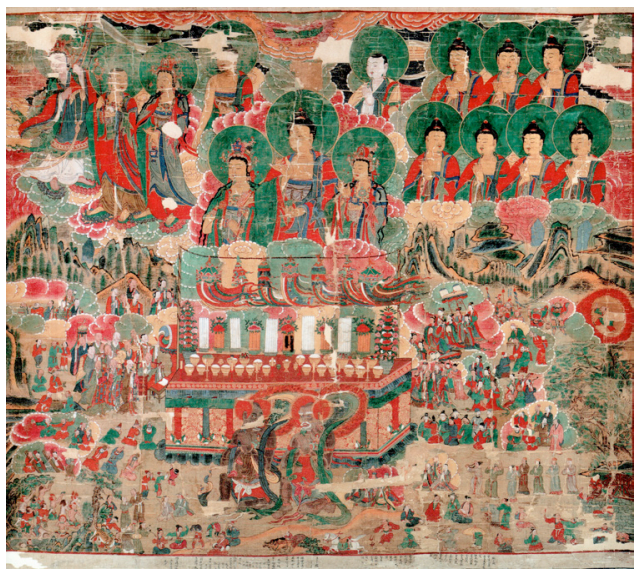

Fig. 7. Sweet-Dew Painting (Ch’ŏngnyongsa Kamnodo 靑龍寺 甘露圖), 1692, ink and color on hemp cloth, $204.0 \times 236.5$ cm, Ch’ŏngnyongsa, Kyŏnggi Province, Korea (After Sŏngbo munhwajae yǒn'guwŏn, Han'guk ŭi purhwa, vol. 29, Fig. 16)

Kamnodo 西敎寺 甘露圖, 1590) positions the Seven Buddhas at the center encircling the triad (Fig. 8). ${ }^{12}$

12 Kim Sŭnghŭi contends that these arrangements had been occasioned by the influence of Pure Land faith, which dominated the early phase of iconographic development of the Sweet-Dew painting. Kim, "Uhak munhwajaedan sojang Kamnot'aenghwa: tosang ǔi ǔimi wa hwamyǒn kusǒng ŭl chungshim ǔro” 宇鶴文化財團所藏 甘露幀畫: 圖像의 意味와 畫面 構成을 중심으로, Tanho munhwa yŏn'gu 5 (December 2000): 17. For a similar view, see Pak Ǔnkyŏng, Chosŏn chŏngi purhwa yŏn'gu, 


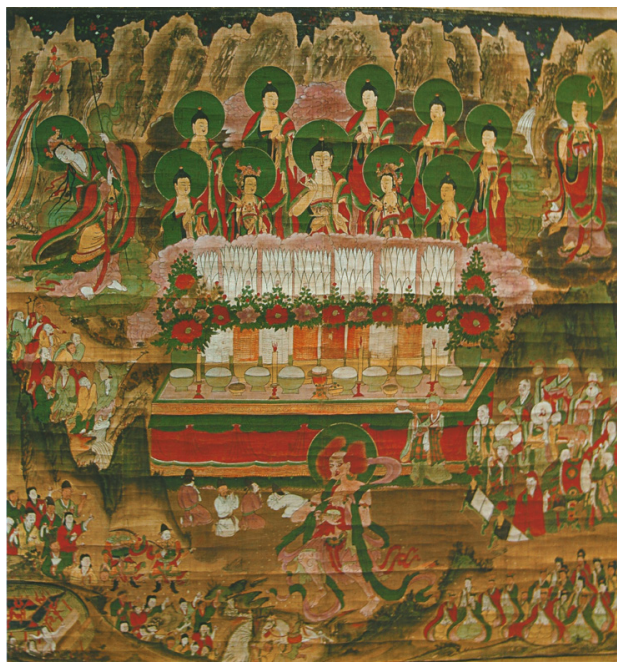

Fig. 8. Sweet-Dew Painting (Saikyō-ji Kamnodo 西敎寺 甘露圖), 1590, ink and color on hemp cloth, $139.0 \times 127.8$ cm, Saikyō-ji, Shiga Prefecture, Japan (After Kang Upang and Kim Sŭng-hŭi, Kamnot'aeng, Fig. 45)

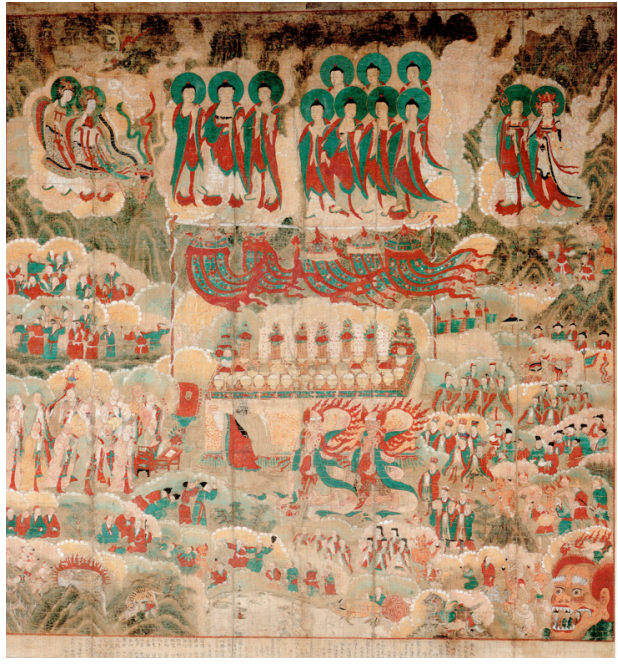

Fig. 9. Sweet-Dew Painting (Kamnodo 甘露圖), 1681, ink and color on silk, $200.0 \times 210.0 \mathrm{~cm}$, Uhak Cultural Foundation (After T'ongdosa sǒngbo pangmulgwan, Chosŏn shidae Kamnot'aeng: Kamno, vol. 2, Fig. 7)

Despite such arrangements, however, in the entirety of the genre - the Amitābha triad does not constitute its primary iconography—often being absent as previously seen in the Posŏksa example (Fig. 5). Additionally, the Sweet-Dew painting in the Uhak Cultural Foundation (Kamnodo 甘露圖, 1681) arranges the Seven Buddhas in the position comparable to the aforementioned Ssanggyesa painting (Fig. 9). It juxtaposes the Seven Buddhas exceptionally with the Three Buddhas, placing each on either side of the central axis. Therefore, excluding only a few cases, a single composition of the Seven Buddhas engages the central position among other deities in the Sweet-Dew painting (Table 1). ${ }^{13}$

368.

13 The Sweet-Dew painting (Kamnodo 甘露圖, $18^{\text {th }}-19^{\text {th }}$ cent.) in the collection of Korea University Museum is another exceptional case. It exhibits a centrally positioned group of five seated and two standing figures of Buddhas. However, it still belongs to the fifty-seven specimens representing a single composition of the Seven Buddhas in table 1, since the accompanying cartouche confirms the assemblage as the representation of the Seven Buddhas. For an illustration, see Kang Upang and Kim Sŭnghŭi, Kamnot'aeng 甘露幀, $2^{\text {nd }}$ ed. (Sǒul: Yegyǒng, 2010), 179, fig. 21. The cartouches appended to the painting is listed in T'ongdosa sǒngbo pangmulgwan, Chosǒn shidae Kamnot'aeng: Kamno 朝鮮時代 甘露幀: 甘露(Yangsan: T’ongdosa sǒngbo pangmulgwan, 2005), 2:133. 
〈Table 1〉 The Assemblage of Buddhas in the Sweet-Dew Painting of the Chosŏn Period (1392-1910)

\begin{tabular}{|c|c|c|c|c|}
\hline Mode of Configuration & Five $\mathrm{Bu}$ & & Seven Buddhas & \\
\hline \multirow{3}{*}{$\begin{array}{l}\text { Single } \\
\text { composition }\end{array}$} & \multirow{3}{*}{ At the center } & \multirow{3}{*}{3} & At the Center & 57 \\
\hline & & & $\begin{array}{l}\text { On the side or encircled around } \\
\text { the Amitābha triad }\end{array}$ & 3 \\
\hline & & & $\begin{array}{l}\text { At the central plane juxtaposed with } \\
\text { another group of Buddhas }\end{array}$ & $2^{14}$ \\
\hline \multirow{2}{*}{$\begin{array}{l}\text { Variant } \\
\text { composition }\end{array}$} & \multirow{2}{*}{ - } & \multirow{2}{*}{-} & $\begin{array}{l}\text { A group of six Buddhas aligned with } \\
\text { the Amitābha triad }\end{array}$ & 3 \\
\hline & & & $\begin{array}{l}\text { The Amitābha Triad disjoined from } \\
\text { the group of six Buddhas }\end{array}$ & 6 \\
\hline Subtotal & \multicolumn{2}{|c|}{3} & \multicolumn{2}{|l|}{71} \\
\hline Total & \multicolumn{4}{|c|}{74} \\
\hline
\end{tabular}

Second, the assemblages of the Seven Buddhas are configured in less conspicuous manners while likewise presiding over the upper register. Altogether nine specimens demonstrate such variant formations through rendering a group of six figures of Buddhas and the Buddha Amitābha, the last constituent of the Seven Buddhas, discretely accompanied by two attending bodhisattvas Avalokiteśvara and Mahāsthāmaprāpta (or Kṣitigarbha) (Table 1). Among them, three are relatively straightforward to identify. For example, the Sweet-Dew painting (Sudosa Kamnodo 修道寺 甘露圖, 1786) in

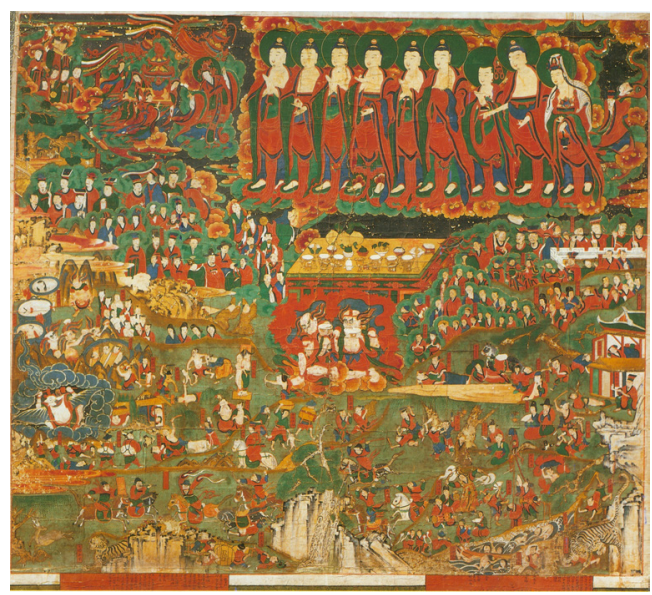

Fig. 10. Sweet-Dew Painting (Sudosa Kamnodo 修道寺 甘露圖), 1786, ink and color on silk, 204.0×189.0 cm, T'ongdosa Museum (After Kang Upang and Kim Sŭnghǔi, Kamnot'aeng, Fig. 19) the T'ongdosa Museum horizontally aligns a group of six Buddhas consecutively with the Amitäbha triad (Fig. 10). ${ }^{15}$ Meanwhile, the remaining six paintings

14 It includes the Ssanggyesa Kamnodo 雙溪寺 甘露圖 which represents both the Seven Buddhas and the Five Buddhas.

15 Two others examples are housed in the Ssanggyesa Museum (Unhŭngsa Kamnodo 雲興寺 甘露圖, 1730) and Wǒn'gwang 
station the triad independently separated from the group of six Buddhas. For example, the SweetDew painting from the Paek'ung Hermitage of Ǔnhaesa (Ǔnhaesa Paek'ŭngam Kamnodo 銀海寺 百興庵 甘露圖, 1792) assembles six Buddhas at the center above a pair of hungry ghosts, while positioning the Amitābha triad on the far right divorced from the main assemblage (Fig. 11). ${ }^{16}$ Accordingly, when the Sweet-Dew painting presents an assemblage consisted only of six figures of Buddhas, Amitābha joins the group, either on its contiguous side or detached from it, to form a complete representation of the Seven Buddhas.

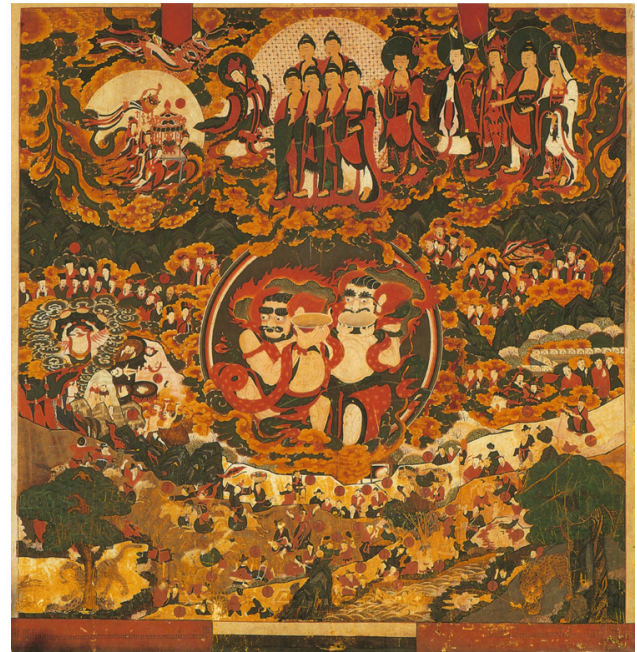

Fig. 11. Sweet-Dew Painting (Ǔnhaesa Paek'ǔngam Kamnodo 銀海寺百興庵 甘露圖), 1792 , ink and color on silk, $196.5 \times 196.0 \mathrm{~cm}$, Paek'ŭngam, Ǔnhaesa, North Kyŏngsang Province, Korea (After Sŏngbo munhwajae yǒn'guwǒn, Han'guk ǔi purhwa, vol. 30, Fig. 45)

\section{The Mantras of Invoking the Names of Buddhas Prescribed in the Buddhist Texts on Food-Bestowal Practices}

The Buddhist texts associated with the ritual praxis of food bestowal offer instructions for invoking an assemblage of Buddhas, for the immediacy of their divine capacity in effectuating the salvific power of the rites. They include several canonical scriptures from which Rolf W. Giebel categorizes as a "group of texts describing the rites for the dead" (T. 1313-1321) and a body of redacted editions of the Water-Land and the Food-Bestowal manuals circulated in the Chosŏn period. ${ }^{17}$ Particularly, the latter texts of the

University Museum (Kamnodo 甘露圖, 1750). For sources of illustrations, see note 8 above.

16 Five other examples include the paintings in private collections (Kamnodo 甘露圖, 1661 and Yǒch'ŏn Hŭngguksa Kamnodo

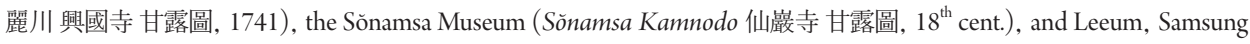
Museum of Art (Kamnodo 甘露圖, $18^{\text {th }}$ cent.) and the underdrawing ( $18^{\text {th }}$ cent.) by Monk Pyŏngjin 炳震. Ibid.

17 Giebel, "Taishō Volumes 18-21," in Esoteric Buddhism and the Tantras in East Asia, ed. Charles D. Orzech, Henrik H. Sørensen, and Richard K. Payne (Leiden: Brill, 2011), 35. 
sixteenth century merit attention for their prevalence closely linked to the contemporaneous emergence of the Sweet-Dew painting; the period, in fact, marked a historical juncture that saw a proliferation of the Water-Land manuals and, more importantly, the inception of independent publications of the FoodBestowal manuals. ${ }^{18}$

However, despite their joint interest in providing the method of food bestowal, the aforementioned collections of texts put forward variable prescriptions for invoking the names of the Buddhas whereby the rite exercises its efficacy. On what ground do we then determine the textual foundation of the assemblage of Buddhas portrayed in the Sweet-Dew painting? Pursuant to the liturgical aim of the food bestowal, the most preeminent features contributing to the pictorial representation of the assemblage are arguably the presence of the Sweet-Dew King (Kr. Kamnowang yŏrae 甘露王如來; Skr. Amṛta Rājāya Tathāgata) and his divine task directly connected to the salvific capacity of consumption, as also inferred from the title attributed to the genre. Based on this premise, the following pages will identify the Sweet-Dew King's liturgical connection to the food bestowal and the precise chronological juncture of its advent, in order to shed light on the textual basis that has shaped the Seven Buddhas in the Sweet-Dew painting.

As early as the eighth century, the Chinese translations of esoteric scriptures have advanced the mantra (jineon 畺言) recitations involving an elaboration of the names of Buddhas for the execution of the rites of food bestowal. ${ }^{19}$ One of the earliest texts, the Foshuo jiuba yankou egui tuoluoni jing 佛說救拢焰口餓鬼陀羅尼經 (Buddha’s Discourse on the Dhāranī Scripture for Saving the FlamingMouth Hungry Ghost, hereafter Flaming-Mouth Sūtra) (T. 1313; K. 1302), details the Buddha's instruction to Ānanda the method of food bestowal that requires invoking the Four Buddhas (sayorae 四如來or Four Tathāgatas) in the following order:

18 For a discussion of the rapid increase in the publications of Buddhist ritual texts, particularly of the Water-Land manuals, in the sixteenth and seventeenth centuries, see Nam Hǔisuk, "16-18 segi pulgyo ǔishikchip ǔi kanhaeng kwa pulgyo taejunghwa" 16-18세기 佛敎儀式集의 간행과 佛教大衆化, Han'guk munhwa 34 (December 2004): 115-120; idem, "Publication of Buddhist Literary Texts: The Publication and Popularization of Mantra Collections and Buddhist Ritual Texts in the Late Chosonn Dynasty," Journal of Korean Religions 3, no. 1 (April 2012): 16-20. The emergence of independent publications of the Food-Bestowal manuals in the sixteenth century is discussed in Pak, "Gamno Paintings," 83-95.

19 An overview of the development of food-bestowal practices in China and the related esoteric texts is included in Charles D. Orzech, "Esoteric Buddhism and the Shishi in China," in The Esoteric Buddhist Tradition, ed. Henrik H. Sørensen (Copenhagen: The Seminar for Buddhist Studies, 1994), 51-72; for a comprehensive study on this topic, see Hun Y. Lye, "Feeding Ghosts: A Study of the Yuqie Yankou Rite" (PhD diss., University of Virginia, 2003). 
1. Duobao rulai多寶如來 (Many Treasures)

2. Miaoseshen rulai 妙色身如來 (Wonderful-Form Body)

3. Guangboshen rulai 廣博身如來 (Expansive Body)

4. Libuwei rulai 離怖畏如來 $(\text { Separated from Fear })^{20}$

In undertaking the procedure, the text also explicated the power (Kr. kaji 加持; Skt. adhișthāna) generated by each name of the Buddha. Most notable among the Four Buddhas is the Expansive Body (Kr. Kwangbakshin 廣博身), whose divine power assumes a direct connection to consumption enabling the throats of departed spirits to open and fulfill their hunger. ${ }^{21}$

In three other esoteric scriptures possibly of later date, the aforementioned formula underwent a process of expansion to specify the mantras of either the Five or the Seven Buddhas (Table 2). ${ }^{22}$ For example, as enumerated below, the Shi zhu egui yinshi ji shui fa 施諸餓鬼飲食及水法 (Bestowing Food and Drink to All Hungry Ghosts and the Water Method, hereafter Bestowing Food and Water Method) (T.1315) prescribes the names of the Five Buddhas:

1. Baosheng rulai 寶勝如來 (Precious Victory)

2. Miaoseshen rulai 妙色身如來 (Wonderful-Form Body)

3. Ganluwang rulai 甘露王如來 (Sweet-Dew King)

4. Guangboshen rulai 廣博身如來 (Expansive Body)

5. Libuwei rulai 離怖畏如來 (Separated from Fear) ${ }^{23}$

From the previous sequence of mantras, the Bestowing Food and Water Method replaced the Many

20 T. 1313, 21.465a12-a26.

21 “由稱廣博身如來名號加持故, 能令諸鬼咽喉寬大, 所施之食, 恣意充飽, ” T. 1313, 21.465a22.

22 These texts are commonly attributed to Amoghavajra (Bukong Jin'gang 不空金剛, 705-774), but they probably date from the Yuan period (1271-1368). Charles D. Orzech "Fang Yankou and Pudu: Translation, Metaphor, and Religious Identity," in Daoist Identity: History, Lineage, and Ritual, ed. Livia Kohn and Harold D. Roth (Honolulu: University of Hawai' i Press, 2002), 221; Lye, "Feeding Ghosts," 337-350. Daniel B. Stevenson also advocates Lye's argument. Stevenson, "Buddhist Ritual in the Song," in Modern Chinese Religion, ed. John Lagerwey and Pierre Marsone (Leiden: Brill, 2015), 1:359-340n44. The Korean Buddhist Canon (Koryŏ taejanggyŏng 高麗大藏經) does not include the three canonical texts listed in table 2. See Lewis R. Lancaster and Sung-bae Park, The Korean Buddhist Canon: A Descriptive Catalogue (Berkeley: University of California Press, 1979), 162.

23 T. 1315, 21.467c3-468a1. 
〈Table 2〉 The Invocation of Buddhas Prescribed by the Buddhist Texts Expounding the Method of Food Bestowal ${ }^{24}$

\begin{tabular}{|c|c|c|c|}
\hline \multicolumn{2}{|r|}{ Five Buddhas } & \multicolumn{2}{|c|}{ Seven Buddhas } \\
\hline $\begin{array}{l}\text { Esoteric } \\
\text { Buddhist } \\
\text { Canon }\end{array}$ & $\begin{array}{l}\text { Shizhu egui yinshi ji shuifa } \\
\text { 施諸餓鬼飲食及水法 } \\
\text { (T. 1315) }\end{array}$ & $\begin{array}{l}\text { Esoteric } \\
\text { Buddhist } \\
\text { Canon }\end{array}$ & $\begin{array}{l}\text { Yuqie jiyao jiu Anan tuoluoni } \\
\text { yankou guiyi jing 瑜伽集要救 } \\
\text { 阿難陀羅尼焰口軌儀經 } \\
\text { (T. 1318) } \\
\text { Yuqie jiyao yankou shishi yi } \\
\text { 瑜伽集要焰口施食儀 } \\
\text { (T. 1320) }\end{array}$ \\
\hline $\begin{array}{l}\text { Joseon } \\
\text { Redactions of } \\
\text { the Water-Land } \\
\text { manuals }\end{array}$ & 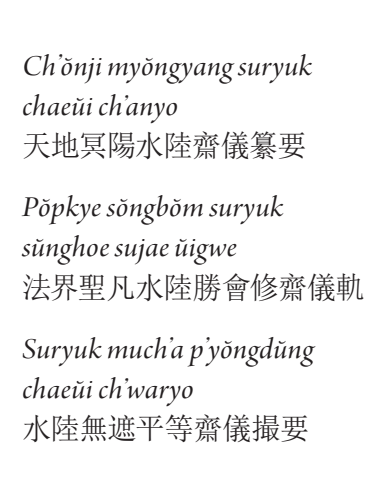 & $\begin{array}{l}\text { Joseon } \\
\text { Redactions of } \\
\text { the Food-Bestowal } \\
\text { manuals }\end{array}$ & $\begin{array}{l}\text { Samdan shishingmun } \\
\text { 三壇施食文 } \\
\text { Chǔngsu sǒngyoshishik ǔimun } \\
\text { 增修禪敉施食儀文 } \\
\text { Taechial samyorngil yŏnghon } \\
\text { shishik ǔimun } \\
\text { 大刹四明日迎魂施食儀文 } \\
\text { Unsudan 雲水壇 } \\
\text { (Unsudan kasa 雲水壇謌詞) } \\
\text { Chebanmun 諸般文 }\end{array}$ \\
\hline
\end{tabular}

Treasures (Kr. Tabo yŏrae 多寶如來) with the Precious Victory (Kr. Posŭng yŏrae 寶勝如來) and newly included the Sweet-Dew King. ${ }^{25}$ The Precious Victory thereby acquired the equivalent capacity of the Many Treasures and the Sweet-Dew King the power to "[confer] the heart of the Dharmakāya, causing the attainment of definite bliss. ${ }^{26}$ Meanwhile, the Expansive Body maintained his engagement in expanding the throats of departed spirits and thus allowing them to enjoy the "wonderful taste."

Similarly, the Chosonn manuals of the Water-Land espoused the mantras of the Five Buddhas and their respective involvements in the food bestowal (Table 2). Among the three most widespread editions in the sixteenth century, the Suryuk much'a p'yŏngdŭng chaeŭi ch'waryo 水陸無遮本等齋儀撮要 (The

\footnotetext{
24 The table is revised from Pak, "Gamno Paintings," 146, table 2.

25 “由稱多寶如來名號加持故, 能破一切諸鬼多生已來慳恪惡業, 即得福德圓滿,” T. 1313, 21.465a14; “基謨寶勝如來除慳貪 業福德圓滿, ” T. 1315, 21.467c07.

26 “曩謨甘露王如來灌法身心令受快樂,” T. 1315, 21.467c17. The translation is adopted from Lye, “Feeding Ghosts, ” 430.

27 “基謨廣博身如來咽喉寬大受妙味, ” T. 1315, 21.467c22.
} 
Abbreviated Ritual for the Water and Land Unobstructed, Equal Feast), for example, includes a chapter on the invocation of Buddhas (sŏnyang sŏngho p'yŏn 宣揚聖號篇), which presents the mantras of the Five Buddhas accompanied with the illustrations of corresponding mudrās. ${ }^{28}$ Apart from the Many Treasures, who replaces the Precious Victory, the names of the Buddhas and their functional link to the food bestowal correlate to the Bestowing Food and Water Method, albeit in different order. In fact, the given configuration has prevailed as early as the fourteenth century in the Ch'onji myongyang suryuk chaeūi ch'anyo 天地冥陽水陸齋儀纂要 (Essential Rules for the Ceremony of the Heaven and Earth, Day and Night, Water and Land Feast) compiled by the Koryŏ monk Chugam Yugong 竹菴䣭公 (n.d.). ${ }^{29}$ Moreover, another popular Chosŏn edition, the Pŏpkye sŏngbŏm suryuk sŭnghoe sujae ŭigwe 法界聖凡水陸勝會修齊儀軌 (The Rules for the Excellent Assembly for the Observation of the Feast for the Dharmadhātu's Holy and World in Water and on Land), likewise specify the Five Buddhas assuming similar powers. ${ }^{30}$

Above all, the texts which expound the Seven Buddhas merit special attention as regards the iconographic arrangements of the Sweet-Dew painting examined in the previous section. They include two canonical texts and several Chosonn redactions of the Food-Bestowal manual emerged around the sixteenth century (Table 2). First, the Yuqie jiyao jiu Anan tuoluoni yankou guiyi jing 瑜伽集要救阿難陀 羅尼焰口軌儀經 (The Scripture from the Essentials of Yoga Teachings on the Dhāranī Flaming-Mouth Rite for Saving Ānanda) (T. 1318) and the Yuqie jiyao yankou shishi yi 瑜伽集要焰口施食儀 (Essentials of Yoga Teachings for Bestowing Food to Flaming Mouths) (T. 1320) uniformly set forth the names of the Seven Buddhas as below:

1. Baosheng rulai 寶勝如來 (Precious Victory)

2. Libuwei rulai 離怖畏如來 (Separated from Fear)

3. Guangboshen rulai 廣博身如來 (Expansive Body)

4. Miaoseshen rulai 妙色身如來 (Wonderful-Form Body)

28 For example, see HPC 1:636a9-637a6.

29 For example, see HPC 2:240a. The original Koryo edition is not currently extant, but the postscript of Yi Chehyŏn 李齊賢 (12871367) written in 1342 attached to later publications reveals the name of the compiler; for example, see the Ssangbongsa 雙峰寺 edition (1562) preserved in Tongguk University Library.

30 For example, see HPC 1:609a16-610b8. The text is also commonly referred to as Chibanmun 志盤文 (Text of Zhipan) after the name of the original compiler, the Chinese Tiantai 天台 monk Siming Zhipan 四明志磐 (fl. $13^{\text {th }}$ cent.). 


\section{Duobao rulai 多寶如來 (Many Treasures) \\ 6.Amituo rulai 阿彌陀如來 (Infinite Light) \\ 7. Shijian guangda weide zizai guangming rulai 世間廣大威德自在光明如來 (Physical World, Wide and Large, Authority and Virtue, Unrestricted, and Bright) ${ }^{31}$}

The list has been configured fundamentally based on the arrangement of the Five Buddhas, while additionally including the Many Treasures, Infinite Light (Kr. Amit'a; Skt. Amitābha) and the Physical World, Wide and Large, Authority and Virtue, Unrestricted, and Bright (Kr. Segan kwangdae widǒk chajae kwangmyŏng yŏrae 世間廣大威德自在光明如來) and omitting the Sweet-Dew King. In both texts, the capacity of opening the needle-like throats of departed spirits (or hungry ghosts) remained connected to the Expansive Body, and its description further specified the salvific substance to be consumed as the "sweet dew." 32

Second, the Chosonn redactions of the Food-bestowal manuals likewise expound the Seven Buddhas (Table 2). However, they are clearly distinguished for their inclusion of the Sweet-Dew King after the earlier arrangement in the Bestowing Food and Water Method. Notwithstanding, these manuals associate the Sweet-Dew King with the capacity that had been previously given to the Expansive Body, reversing the liturgical tasks between the two deities. Such emendation initially occurred in the Samdan shishingmun 三壇施食文 (Text of the Three-Altar Food Bestowal) compiled in 1496 (Table 3). ${ }^{33}$ Within

31 T. 1318, 21.471a1-a22; T. 1320, 21.478a26-479a12.

32 “若聞廣博身如來名號. 能令汝等餓鬼針咽業火停燒清涼通達. 所受飲食得甘露味,” T. 1318, 21.471a8；T. 1320, $21.478 \mathrm{~b} 28$.

33 HPC 1:470a1-490b. Grand Queen Dowager Insu 仁粹 (1437-1504) and Queen Chŏnghyŏn 貞顯 (1462-1530) commissioned the carving of the Samdan shishingmun jointly with the Chinón'gwon'gong 眞言勸供 (Instructions on Making Offerings with Mantras) for the repose of the deceased King Sŏngjong 成宗 (r. 1469-1494). Monk Hakcho 學祖 (n. d.) is known to have edited the two texts and compiled them into one book; and four hundred copies were printed at Wón'gaksa 圓覺寺 in the capital. In spite of the fact that such altered configuration of the Seven Buddhas is first seen in the Samdan shishingmun, the impetus for the change is uncertain. We may only surmise that the text is a redacted compilation premised on the prevalent contemporaneous manuals of the Water-Land (which had been already adapted to the liturgical setting of Joseon Buddhism) and the original Chinese manual of the Food-Bestowal authored by Mengshan Deyi 蒙山德異 (ca. 1232-1308), prior to the publications of the Chŭngsu sŏn'gyo shishik ŭimun 增修禪敎施食儀文 (Revised and Augmented Ritual Manual for the Performance of Food Offerings in Sŏn and Kyo) and Taech'al samyŏngil yŏnghon shishik ǔimun 大刹四明日迎魂施食儀文 (Text for the Ritual of Welcoming Back the Spirits with Food in Great Temples on the Four Bright Days). Mengshan's authorship nevertheless needs further investigation. See Pak, "Gamno paintings," 88n199. 
〈Table 3〉 The Seven Buddhas and Their Liturgical Tasks Stipulated in the Samdan shishingmun (Text on Three-Altar Offerings) $^{34}$

\begin{tabular}{|c|c|}
\hline Seven Buddhas & Liturgical Tasks \\
\hline $\begin{array}{l}\text { Tabo yŏrae } \\
\text { 多寶如來 } \\
\text { (Many Treasures) }\end{array}$ & $\begin{array}{l}\text { Extinguishes the greedy, parsimonious nature of all departed spirits and fulfills } \\
\text { them with Buddha's teaching } \\
\text { 某靈駕法界亡魂 破除慳 貪法財具足 }\end{array}$ \\
\hline $\begin{array}{l}\text { Posǔng yŏrae } \\
\text { 寶勝如來 } \\
\text { (Precious Victory) }\end{array}$ & $\begin{array}{l}\text { Helps all departed spirits to abandon inferior modes of existence and elevates } \\
\text { their path for existence } \\
\text { 某靈駕法界亡魂 各捨惡 道隨意超升 }\end{array}$ \\
\hline $\begin{array}{l}\text { Myosaekshin yŏrae } \\
\text { 妙色身如來 } \\
\text { (Wonderful-Form Body) }\end{array}$ & $\begin{array}{l}\text { Transforms the filthy and uncanny appearance of all departed spirits into one } \\
\text { that is pure and gentle } \\
\text { 某靈駕法界亡魂 離醜 陃形相好圓滿 }\end{array}$ \\
\hline $\begin{array}{l}\text { Kwangbakshin yŏrae } \\
\text { 廣博身如來 } \\
\text { (Expansive Body) }\end{array}$ & $\begin{array}{l}\text { Helps all departed spirits to free themselves from the body of the six realms of } \\
\text { existence in order to obtain the dharma-body } \\
\text { 某靈駕法界亡魂 捨六凡身悟清淨虛空身 }\end{array}$ \\
\hline $\begin{array}{l}\text { Ip'ooe yǒrae } \\
\text { 離怖畏如來 } \\
\text { (Separated from Fear) }\end{array}$ & $\begin{array}{l}\text { Helps all departed spirits to be free from fear and to obtain the joy of } \\
\text { enlightenment } \\
\text { 某靈駕法界亡魂 離諸怖畏得涅槃樂 }\end{array}$ \\
\hline $\begin{array}{l}\text { Kamnowang yŏrae } \\
\text { 甘露王如來 } \\
\text { (Sweet-Dew King) }\end{array}$ & $\begin{array}{l}\text { Opens the needle-like throats of all departed spirits to taste the sweet dew } \\
\text { 某靈駕法界亡魂 咽喉開通獲甘露味 }\end{array}$ \\
\hline $\begin{array}{l}\text { Amit’a yŏrae } \\
\text { 阿彌陀如來 } \\
\text { (Infinite Light) }\end{array}$ & $\begin{array}{l}\text { Helps all departed spirits to be reborn in the realm of paradise } \\
\text { 某靈駕法界亡魂 隨念超生極樂世界 }\end{array}$ \\
\hline
\end{tabular}

the offertory services of the three altars (comprising high, middle and low altars), the food bestowal of the low altar particularly involved the procedure of invoking the Seven Buddhas in facilitating the salvation for departed spirits (manghon 亡魂 or hawi 下位, “the low-status beings"). Starting with the Many Treasures, the text enumerates the names of the Buddhas to be invoked for their divine powers, to transfigure the departed spirits into the condition suitable for consuming the sweet dew and ultimately to bestow upon them a rebirth in paradise..$^{35}$ In the process, notably, the Sweet-Dew King confers his

34 The table is revised from Pak, "Gamno Paintings," 149-150, table 3.

35 HPC 1:481b17-483a14. The Many Treasures and Sweet-Dew King are regarded as a single entity (tongch'e 同體), respectively, with the Precious Victory (Kr. Posǔng yǒrae 寶勝如來) and Infinite Light (Amit’a yŏrae 阿彌陀如來). Sim Sanghyŏn, Pulgyo ŭishik kangnon 佛㸚儀式各論, vol. 3, Iryong ŭibŏm 日用儀範 (Sǒul: Han'guk pulgyo ch'ulp'anbu, 2002), 278-291. In this regard, the configuration of the Seven Buddhas shown in table 3 can be an expansion of the Five Buddhas specified in the Bestowing Food and Water Method. 
blessings to "open the needle-like throats of departed spirits and taste the sweet dew," while the Expansive Body "helps all departed spirits to free themselves from the body of the six realms of existence in order to obtain the dharma-body" (Table 3). The subsequent editions of the Food-Bestowal manual, which began to circulate in the sixteenth century, also detail the instruction equivalent to the Samdan shishingmun (Table 2). ${ }^{36}$ Accordingly, the recitations of the names of the Seven Buddhas became standard for the food bestowal of the low altar (hadan shishik 下壇施食), distinctively implementing the link between the Sweet-Dew King and the liturgical task of opening of the needle-like throats of departed spirits.

\section{The Sweet-Dew King among the Seven Buddhas}

Correlating with the Sweet-Dew King's immediate association to the salvific scheme of the food bestowal, his presence among the Seven Buddhas is discernible in several extant specimens of the SweetDew painting. In fact, the four different titles traditionally ascribed to the Sweet-Dew painting also include “Kamnowang t’aeng” 甘露王幀 (a hanging scroll of the Sweet-Dew King), ${ }^{37}$ and thus, suitably, the title “Sweet-Dew King” (Kamnowangdo 甘露王圖) was commonly used in modern scholarship especially in the 1980s and 90s when the art-historical studies of this Buddhist painting genre began to accumulate in Korea. ${ }^{38}$ Notwithstanding, the iconographic identification of the Sweet-Dew King has not been carefully

36 For example, see HPC 1:368b9-15; HPC 2:575a17-b8; HPC 2:55a8-14.

37 Three other titles found in the written record (hwagi 畫記) attached to several specimens of the Sweet-Dew painting are Hadant'aeng 下壇幀 (a hanging scroll of the Low-Altar), Kamnohoe 甘露會 (Sweet-Dew Assembly) and Kamnot'aeng 甘露幀 (or Kamnot'aenghwa 甘露幀畫, a hanging scroll of the Sweet Dew). Although different titles had prevailed during the sixteenth to eighteenth centuries, only the last-mentioned title continued into the nineteenth century.

38 See Mun Myŏngtae, Han'guk ǔi purhwa 韓國의 佛畫 (Sǒul: Yorrhwadang, 1977), 95-98. The title “Sweet-Dew King” was initiated by Mun Myǒngtae in the late 1970s. The art-historical publications thereafter frequently espoused this title until the “Sweet Dew” (Kamot'aeng 甘露幀 or Kamnodo 甘露圖) gained general acceptance among scholars in the late 1990s. For example, see Kim Jǒnghǔi, Han'guk ǔi mi 韓國美, ed. Kim Wǒnryong et al. (Sŏul: Chungang ilbo, 1984), 16:230-233; An Kwisuk, “Chosǒn hugi purhwasǔng ǔi kyebo wa Ǔigǒym pigu e kwanhan yǒn'gu” 朝鮮後期 佛畫僧의 系譜와 義謙比丘에 관한 研究, Misulsa yŏn'gu 9 (December 1995): 158-164; Yu Mari, “Chosǒnjo Kamnowangdo ǔi yǒn'gu” 朝鮮朝甘露王圖의 研究, in Chsŏnjo purhwa ǔi yŏn'gu 朝鮮朝 佛畫手 研究, ed. An Kwisuk, Kim Chŏnghǔi, and Yu Mari (Sǒngnam: Han'guk chŏngshin munhwa yŏn'guwŏn, 1993), 2:113-180. In Western scholarship, Pierre Cambon similarly contended that the genre takes the theme of the "Amṛta-Raja." See Cambon, L'Art Coréen au Musée Guimet (Paris: Reunion des Museés Nationaux, 2001), 329. 
considered, as the title was treated as one of the appellations of Amitābha and also due to the preference of alternative titles in subsequent or related studies. Particularly with regard to the former, the primary iconographic focus had been the "descent" imagery of the Amitābha triad, which was argued to dominate the illustration featuring the notion of salvation related to Pure Land faith. ${ }^{39}$ Its applicability to the extent works, however, is meager; even the four specimens whose written record ( $h w a g i$ 畫記) bear the title "Kamnowang t'aeng" show iconographic discrepancies not quite corresponding to this explanation. ${ }^{40}$ Moreover, as previously examined in the first section of this paper, the Amitābha triad does not consistently appear in the genre's extant specimens. Equating the Sweet-Dew King with Amitäbha in the pictorial program of the Sweet-Dew painting is seemingly questionable, since the Food-Bestowal manuals also specify the mantras of individual Buddhas and distinguish their capacities. Rather, the potential presence of the Sweet-Dew King can be determined by particularizing the iconography in association to the textual description of his liturgical role.

The Seven Buddhas represented in the Sweet-Dew painting generally lack individual characteristics. Some distinctions are observable in their hand gestures, but they still have limited degree of consistency. Moreover, although there are nine alternative formations of the Seven Buddhas in which Amitabha is depicted independently with two attending bodhisattvas, the identities of the remaining Buddhas are not readily apparent. ${ }^{41}$ On some occasions, however, one particular Buddha can arguably be recognized as the Sweet-Dew King. The most representative example is shown in the Sweet-Dew painting housed in the Peabody Essex Museum (Kamnodo 甘露圖, 1744) (Fig. 12). ${ }^{42}$ In the upper section of the painting, only the Buddha positioned at the very center of the Seven Buddhas appears holding a small bottle with both hands. Notably, this portrayal precisely parallels the representation of the "Sweet-Dew King" in the scroll created as a part of the set of ritual banners of the Seven Buddhas (Ch'iryorraedo 七如來圖) and whose

39 For example, see Mun Myŏngtae, 96; Yu Mari, 114.

40 The four Sweet-Dew paintings include the Ch’ongnyongsa Kamnodo 靑龍寺 甘露圖 (1692), Namjangsa Kamnodo 南長寺 甘露圖 (1701), Haeinsa Kamnodo 海印寺 甘露圖 (1723), and Pongjöngsa Kamnodo 鳳停寺 甘露圖 (1765). For the full text of the written records attached to these paintings, see Kogyŏng et al., Han'guk ǔi purhwa hwagijip 韓國의 佛畫 畫記集 (Sŏul: Sŏngbo munhwajae yǒn' guwǒn, 2011), 968-970, 978.

41 The first section of this article discusses different configurations of the assemblage of the Seven Buddhas represented in the SweetDew painting; see also table 1.

42 For an introduction to the painting, see Susan S. Bean, "The Arts of Life in Late Chosŏn Dynasty Korea," Arts of Asia 36 , no. 3 (May/June 2006): 95-96. 


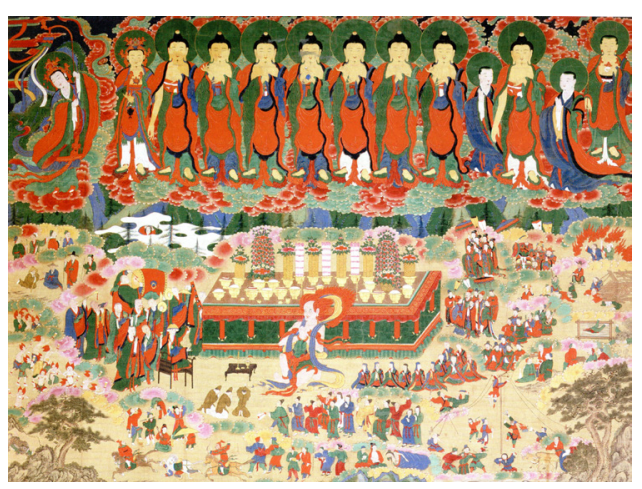

Fig. 12. Sweet-Dew Painting (Kamnodo 甘露圖), 1744, ink and color on silk, $290.0 \times 270.0 \mathrm{~cm}$, Peabody Essex Museum (After Susan S. Bean, "The Arts of Life in Late Chosǒn Dynasty Korea," Fig. 1)

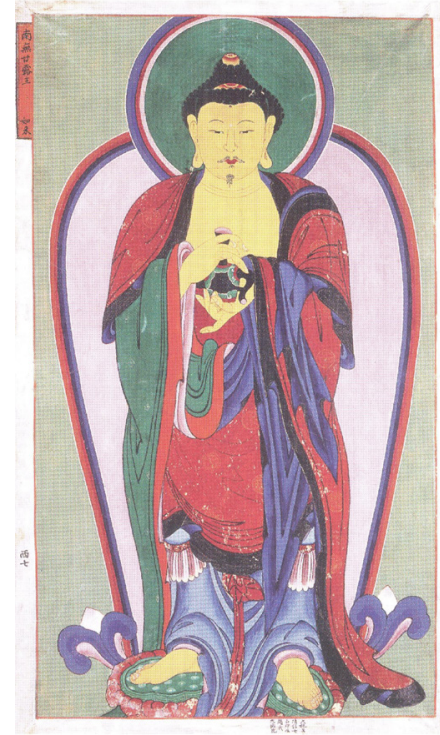

Fig. 13. Sweet-Dew King (Kamnowang 甘露王), one of the banners of the Seven Buddhas (Ch'iryorraedo 七如來圖), late Chosǒn dynasty (1392-1910), ink and color on paper, $127.0 \times 73.5 \mathrm{~cm}$, Chikchi Museum (After Pulgyo chungang pangmulgwan, Pukko p'urün changŏm ǔi segye: Pulchŏn changŏm, 154) name is verified by the accompanying inscription (Namu Kamnowang 南無甘露王) (Fig. 13). The two Buddhas display a striking iconographic affinity even in the manner they are holding the bottle. A further example reinforces this observation. The Sweet-Dew painting in the Guimet Museum collection (Manwŏlsan Suguksa Kamnodo 滿月山 守國寺 甘露圖, 1832) represents one of the Seven Buddhas holding a kundika-shaped bottle that closely resembles the one held by the Sweet-Dew King in the scroll (Fig. 14).

Based on these convincing identifications, we may also associate the Sweet-Dew King with the Buddha holding an alms bowl. Attributed

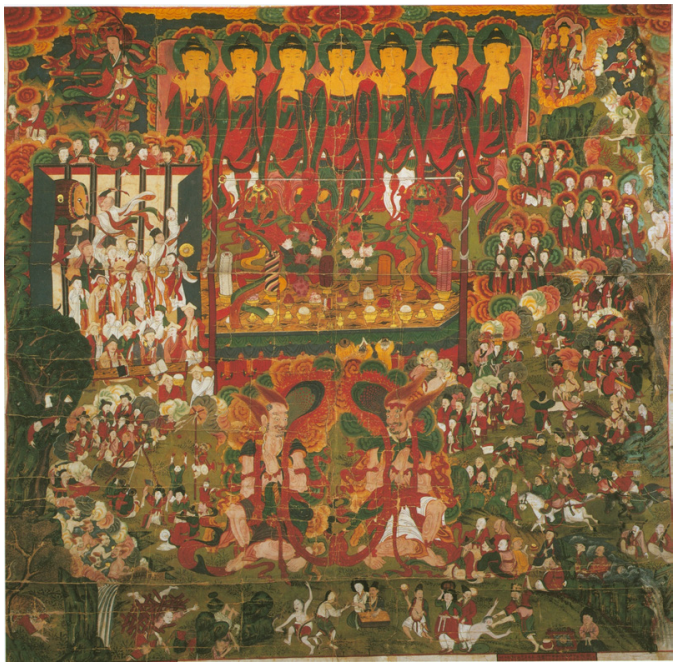

Fig. 14. Sweet-Dew Painting (Manwǒlsan Suguksa Kamnodo 滿月山 守國寺 甘露圖), 1832, ink and color on silk, 192.0×194.2 cm, Guimet Museum (After Kang Upang and Kim Sŭnghǔi, Kamnot'aeng, Fig. 27) 
with either a small bottle or a bowl, the Sweet-

Dew King seems to have effectively displayed his liturgical role among the Seven Buddhas, which involves enabling departed spirits to consume (or taste) the sweet dew by opening their needle-like throats, after the specifications of the FoodBestowal manuals discussed in the previous section. Such liturgical significance of the SweetDew King is especially articulated in the Haeinsa Sweet-Dew painting (Haeinsa Kamnodo 海印寺 甘露圖, 1723) (Fig. 15). While the other Buddhas are uniformly depicted with their palms joined together, the Buddha standing at the right end of the assemblage is holding a small bowl in one hand and the opposite hand lowered

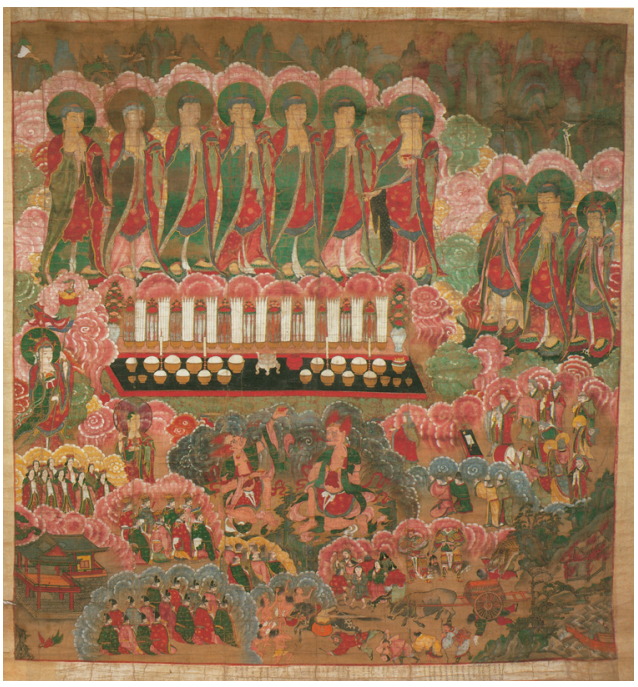

Fig. 15. Sweet-Dew Painting (Haeinsa Kamnodo 海印寺 甘露圖), 1723, ink and color on ramie cloth, 275.0× $261.0 \mathrm{~cm}$, Haeinsa Museum (After Sŏngbo munhwajae yǒn'guwǒn, Han'guk ǔi purhwa, vol. 5, Fig. 88) in the direction of one of the two hungry ghosts below the ritual altar. Seemingly in response to this action, the hungry ghost tilts its head backward to look up and raises one of its alms bowls towards the Buddha. The visual connection between the Buddha and the hungry ghost is exceptionally explicit. In fact, this piece is one of the four extant specimens that bears the title "Kamnowang t'aeng," reasonably in reference to the Buddha portrayed with a small bowl. ${ }^{43}$ Although such degree of visual specification is scarcely seen in the Sweet-Dew paintings, the genre seems to have distinguished the Sweet-Dew King already at the outset of its creation. Two of the six extant specimens from the sixteenth century in the collections of Yakusen-ji (Yakusen-ji Kamnodo 藥仙寺 甘露圖, 1589) and the National Museum of Korea (Ryügan-ji Kamnodo 龍岸寺 甘露圖, $16^{\text {th }}$ cent.) portray one of the Seven Buddhas holding a small bowl filled with a solid substance, presumably indicative of an alternative pictorial mode of the Sweet-Dew King's engagement in the food bestowal (Figs. 6, 6-1, and 16).

43 See note 40 above. 


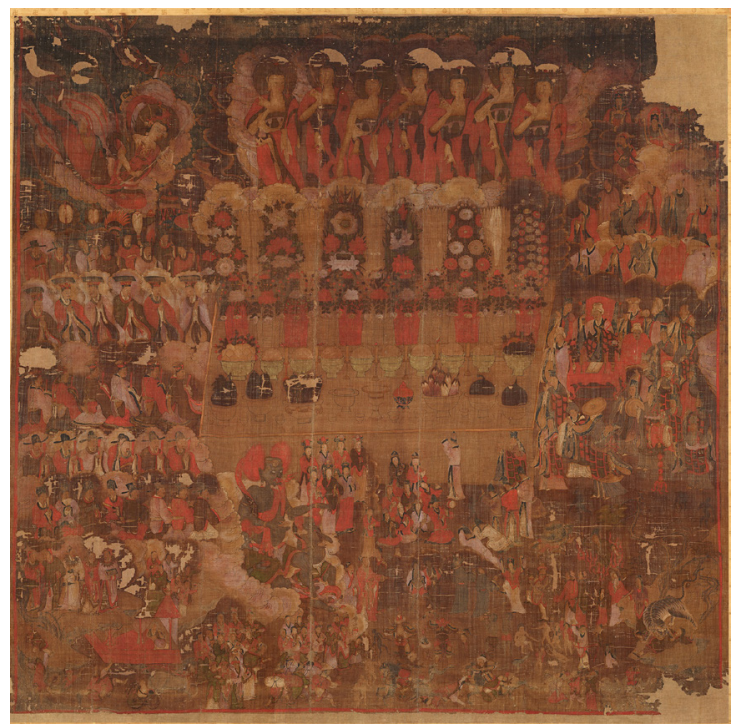

Fig. 16. Sweet-Dew Painting (Ryügan-ji Kamnodo 龍岸寺 甘露圖), $16^{\text {th }}$ century, ink and color on hemp cloth, $240.0 \times 245.0 \mathrm{~cm}$, National Museum of Korea (After Yi Punhǔi et al., Toech'ajŭn munhwajae toesallin munhwajae: Pulgyo munhwajae tashi ikki ikgi, 52)

\section{Conclusion}

The prevalence of the Sweet-Dew Buddhist painting genre testifies a significant liturgical focus on the salvific praxis of the food bestowal in the Choson period. Within the offertory services consulted on the three-altar scheme, the Sweet-Dew painting has become an indispensable part of diverse rituals, both daily and occasional, involving the deliverance of sentient beings belonging to the "low-status" category of existence. For its generic characteristics as an altarpiece for the low altar, the genre's multifarious iconography displays irrefutable associations to a corpus of Buddhist literatures that mutually expound on the food-bestowal practice. ${ }^{44}$ Nevertheless, the most fundamental texts immediately linked to its opportune advancement are arguably the Food-Bestowal manuals that made headway around the sixteenth century, initiating with the Samdan sisikmun and subsequently redacted and independently compiled texts for the performance of bestowing food to departed spirits.

In that framework, as examined in the previous three sections, the representation of the Seven

44 For a list of Buddhist texts related to the iconographies of the Sweet-Dew painting, see Pak Ǔnkyǒng, Chosŏn chŏngi purhwa yŏn'gu, 352-353. 
Buddhas lucidly demonstrates close image-text relations between the Sweet-Dew painting and the FoodBestowal manuals. While allowing some variables in the compositional arrangement, the Sweet-Dew painting has portrayed the Seven Buddhas for their essential role as divine agents in the method of food bestowal, adhering above all to the prescriptions of the Food-Bestowal manuals circulated at the approximate historical juncture that saw its creation for the low ritual altar. Their comparability is distinctively discernible in the identification of the Sweet-Dew King. In manifesting the preeminent power of the Sweet-Dew King, some specimens have shown his presence more straightforwardly by attributing a small bottle or a bowl, directly referencing the liturgical task related to the consumption of the sweet dew. Despite the need for further investigation of the Five Buddhas found in a few early specimens, the prevailing pictorial representation of the Seven Buddhas precisely evinces the textual basis for its assemblage and their liturgical capacity conveyed in the Sweet-Dew painting.

*Keywords: Kamnodo 甘露圖 (Sweet-Dew Painting), shishik 施食 (Food bestowal), Kamnowang 甘露王 (SweetDew King), chillbul 七佛 (Seven Buddhas), obul 五佛 (Five Buddhas)

】 투고일 2020년 6월 16일 | 심사개시일 2020년 6월 26일| 심사완료일 2020년 7월 30일 | 


\author{
Abbreviation \\ HPC Han'guk pulgyo üirye charyo ch'ongsŏ 韓國佛敉儀禮資料叢書 \\ K Koryõ taejanggyǒng 高麗大藏經 \\ $\mathrm{T} \quad$ Taishō shinsū daizōkyō 大正新修大藏經
}

\title{
References
}

\section{Historical records}

Ch'ǒnji myŏngyang suryuk chaeǔi ch'anyo 天地冥陽水陸齋儀纂要. Shinhǔngsa 神興寺 edition. Compiled by Chugam Yugong 竹菴鄭公 (n.d.). 1 fascicle. 1661. HPC 2.

Chebanmun 諸般文. Kŭmsansa 金山寺 edition. 1 fascicle. 1694.HPC 1.

Chŭngsu sŏn'gyo shishik ŭimun 增修禪敎施食儀文. Attributed to Mengshan Deyi 蒙山德異 (1231-1308). 1 fascicle. HPC 1 .

Foshuo jiuba yankou egui tuoluoni jing 佛說救拢焰口餓鬼陀羅尼經. Translated by Amoghavajra (Bukong Jin'gang 不空金剛, 705-774). 1 fascicle.T. 1313 (K. 1302).

Pŏpkye sŏngbŏm suryuk sŭnghoe sujae ŭigwe 法界聖凡水陸勝會修齋儀軌. Zhipan 志磐 (ca. 1220-1275). 1 fascicle. Kongnimsa 空林寺 edition. 1573. HPC 1 .

Samdan shishingmun 三壇施食文. Annotated by Hakcho 學祖 (n. d.). 1 fascicle. 1496. HPC 1.

Shi zhu egui yinshi ji shui fa 施諸拎鬼飲食及水法. Translated by Amoghavajra (Bukong Jin'gang 不空金剛, 705774). 1 fascicle. T. 1315.

Suryuk much'a p'yŏngdŭng chaeǔi ch'waryo 水陸無遮本等齋儀撮要. Tǒkchusa 德周寺 edition. 1 fascicle. 1573. HPC 1.

Taech'al samyöngil yönghon shishik ŭimun 大刹四明日迎魂施食儀文. Attributed to Mengshan Deyi 蒙山德異 (1231-1308). Revised by Tongbin 東賓 (n.d.). Haeinsa 海印寺 edition. 1 fascicle. 1707. HPC 2.

Unsudan 雲水壇. By Ch’ŏnghŏ Hyujǒng 淸虛休靜 (1520-1604). Haeinsa 海印寺 edition. 1 fascicle. 1664. HPC 2.

Yuqie jiyao jiu Anan tuoluoni yankou guiyi jing 瑜伽集要救阿難陀羅尼焰口軌儀經. Translated by Amoghavajra (Bukong Jin'gang 不空金剛, 705-774). 1 fascicle. T. 1318.

Yuqie jiyao yankou shishi yi 瑜伽集要焰口施食儀. Attributed to Amoghavajra (Bukong Jin'gang 不空金剛, 705-774). 1 fascicle. T. 1320. 


\section{Korean Literature}

An Chinho 안진호 (安震湖, 1880-1965). Sŏngmun ŭibŏm 䆁門儀範 [Manuals for Buddhist Rituals]. Kyŏngsǒng: Mansanghoe, 1935. Reprint, Sŏul: Pǒmnyunsa, 2001.

An Kwisuk 안귀숙. “Chosǒn hugi purhwasŭng ǔi kyebo wa Ǔigǒym pigu e kwanhan yǒn'gu” 朝鮮後期 佛畫㒐의 系譜와 義謙 比丘에 관한 研究 [A Study of the Genealogy of Monk Painters in the Late Chosón Period and Monk Ǔigǒym]. Misulsa yǒn'gu 美術史研究 9 (December 1995): 153-201.

Chŏng Myŏnghŭi 정명희. “Chosŏn shidae pulgyo ǔishik ŭi samdan ŭirye wa purhwa yŏn'gu” 朝鮮時代 佛呚儀式의 三壇儀禮와 佛畫 研究 [A Study of the Buddhist Three-Altar Ceremony and Painting of the Chosón Period]. PhD diss., Hongik University, 2013.

Hong Yunsik 홍윤식. Han'guk purhwa ŭi yon'gu 韓國佛畫의 研究 [Korean Buddhist Painting]. Iri: Wǒn'gwang taehakkyo ch'ulp'anbu, 1980.

Kang Pyŏntong 강변동, and Yi Sŭnghŭi 이승희. "Sŏnamsa muhwagi Kamnot'aeng kwa suryuk ŭishingmun ŭi yŏn'gwansǒng koch'al” 仙嚴寺 無畫記 甘露幀과 水陸儀式文의 연관성 古察 [A Comparability Between the Sweet-Dew Painting in Sŏnamsa and the Water-Land Manuals]. Chohyŏng nonch'ong 조형논총 11 (January 2007): 3-16.

Kang Upang 강우방, and Kim Sŭnghǔi 김승희. Kamnot'aeng 甘露幀 [Sweet-Dew Painting]. $2^{\text {nd }}$ ed. Souul: Yegyǒng, 2010.

Kim Chŏnghŭi 김정희. Han'guk ǔi mi 韓國의 美 [Splendors of Korea]. Vol. 16, Chosŏn purhwa 朝鮮佛畫 [Chosǒn Buddhist Painting]. Edited by Kim Wǒnryong et al. Souul: Chungang ilbo, 1984.

Kim Sŭnghŭi 김승희. “Chosŏn shidae Kamnodo ǔi tosang yǒn'gu” 朝鮮時代 甘露圖의 圖像研究 [A Study of the Iconography of the Sweet-Dew Painting of the Chosǒn Period]. Misulsahak yŏn'gu 美術史學研究 196 (December 1992): 5-37.

"Uhak munhwajaedan sojang Kamnot' aenghwa: tosang ŭi ǔimi wa hwamyŏn kusŏng ŭl chungshim ŭro" 宇鶴文化財團 所藏 甘露幀畫: 圖像의 意味와 畫面 構成을 중심으로 [The Sweet-Dew Painting in the Collection of Uhak Cultural Foundation: Significance of Its Iconography and Pictorial Composition]. Tanho munhwa yŏn'gu 丹豪文化研究 5 (2000): 7-39.

“Kamnot'aeng ǔi tosang kwa shinang ǔirye” 甘露幀의 圖像과 信仰 儀禮 [The Iconography of the Sweet-Dew Painting and Buddhist Rituals]. In Kamnot'aeng 甘露幀 [Sweet-Dew Painting]. $2^{\text {nd }}$ ed., edited by Kang Upang and Kim Sŭnghǔi. 435-467. Sŏul: Yegyǒng, 2010.

Kogyŏng 고경, Songch'ŏn 송천, Yi Chongsu 이종수, Hǒ Sangho 허상호, and Kim Chŏngmin 김정민. Han'guk ui purhwa hwagijip 韓國手 佛畫 畫記集 [A Collection of Records from Korean Buddhist Paintings]. Soul: Sŏngbo munhwajae yŏn'guwŏn, 2011.

Mun Myŏngtae 문명대.Han'guk ǔi purhwa 韓國의 佛畫 [Buddhist Paintings of Korea]. Sŏul: Yŏrhwadang, 1977. Myŏngin Auction (Myeongin Auction). The $2^{\text {nd }}$ Myŏngin Auction Sale (June 2017). 
Nam Hǔisuk 남희숙. “16-18 segi pulgyo ǔishikchip ǔi kanhaeng kwa pulgyo taejunghwa” 16-18세기 佛敉儀式集의 간행과 佛教大衆化 [The Popularization of Buddhism and Publication of Buddhist Ritual Texts in the Sixteenth through Eighteenth Centuries]. Han'guk munhwa 韓國文化 34 (December 2004): 97-165.

"Publication of Buddhist Literary Texts: The Publication and Popularization of Mantra Collections and Buddhist Ritual Texts in the Late Chosǒn Dynasty." Journal of Korean Religions 3, no. 1 (April 2012): 9-27.

Pak Chŏngwǒn 박정원. “Chosǒn chŏngi Suryuk'oedo yŏn'gu” 朝鮮前期 水陸會圖 研究 [A Study of the WaterLand Assembly Painting from the First Half of the Chosǒn Period]. Misulsahak yŏn'gu 美術史學研究 270 (June 2011):35-65.

."Chosŏn shidae Kamnodo yŏn'gu” 조선시대 감로도 연구 [Sweet-Dew Painting of the Chosǒn Period]. $\mathrm{PhD}$ diss., Tongguk University, 2020.

Pak Semin 박세민, ed. Han'guk pulgyo ǔirye charyo ch'ongsō 韓國佛敉儀禮資料叢書 [A Complete Works of Korean Buddhist Ritual]. 4 vols. Sŏul: Samsǒngam, 1993.

Pak Ǔnkyŏng 박은경. “Ilbon sojae Chosǒn 16 segi suryuk'oe purhwa, Kamnot'aeng” 일본 소재 조선 16세기 수륙회 불화, 감로탱 [The Sixteenth-Century Paintings of the Water-Land Ritual, the Sweet-Dew Painting, in Japanese Collections]. In Chosŏn shidae Kamnot'aeng: Kamno 朝鮮時代 甘露幀: 甘露 [The Sweet-Dew Painting of the Chosǒn Period: Sweet Dew], edited by T'ongdosa sǒngbo pangmulgwan, 255-300. Vol. 1 of Chosŏn shidae Kamnot'aeng: Kamno 朝鮮時代 甘露幀: 甘露 [The Sweet-Dew Painting of the Chosǒn Period: Sweet Dew]. Yangsan: T’ongdosa sŏngbo pangmulgwan, 2005.

Chosōn chŏngi purhwa yŏn'gu 조선 전기 불화 연구 [The Buddhist Paintings of the First Half of the Chosŏn Period]. Sounl: Shigongat'ŭ, 2008.

Pulgyo chungang pangmulgwan 불교중앙박물관. Pukko p'urŭn changŏm ǔi segye: Pulchŏn changŏm 붉고 푸른 장엄의 세계: 佛殿莊嚴 [Embellishments of Buddha Halls]. Souul: Pulgyo chungang pangmulgwan, 2015.

Sŏngbo munhwajae yŏn'guwŏn 聖寶文化財研究員. Han'guk ǔi purhwa 韓國手 佛畫 [Buddhist Paintings of Korea]. 40 vols. Yangsan: Sŏngbo munhwajae yǒn'guwǒn, 1996-2007.

Sim Sanghyŏn 심상현. Iryong üibŏm 日用儀範 [Daily Ritual Protocols]. Vol. 3 of Pulgyo üishik kangnon 佛㸚儀式各論 [Discussions of Buddhist Rituals]. Sǒul: Han'guk pulgyo ch'ulp’anbu, 2002.

T'ongdosa sǒngbo pangmulgwan 通度寺聖寶博物館. Chosǒn shidae Kamnot'aeng: Kamno 朝鮮時代 甘露幀: 甘露 [The Sweet-Dew Painting of the Chosǒn Period: Sweet Dew]. 2 vols. Yangsan: T'ongdosa sŏngbo pangmulgwan, 2005.

Yi Punhŭi 이분희, Kim Ch'uyǒn 김추연, Sin Yuch'ǒl 신유철, Chǒng Chiyŏn 정지연, Kim Yunhŭi 김윤희, Kim Hyewŏn 김혜원, and Kim Hyŏnsu 김현수, eds. Toech'ajǔn munhwajae toesallin munhwajae: Pulgyo munhwajae tashi ikki 되찾은 문화재 되살린 문화재: 불교 문화재 다시 읽기 [Reclaimed Cultural Assets, Restored Cultural Assets: Rediscovering the Buddhist Cultural Heritage]. Souul: Pulgyo chungang pangmulgwan, 2012.

Yǒn Cheyǒng 연제영. “Uiryejŏk kwanjŏm esǒ Kamnot’aenghwa wa Suryuk’wa ǔi naeyong pigyo” 儀禮的 관점에서 
甘露幀畫와 水陸畫의 內容 비교 [The Comparison Between the Sweet-Dew Painting and the Water-Land Assembly Painting from a Ritualistic Perspective]. Pulgyohak yŏn'gu佛敉學研究 16 (April 2007): 265-297.

Yu Mari 유마리. “Chosǒnjo Kamnowangdo ǔi yŏn'gu” 朝鮮朝甘露王圖의 研究 [A Study of the Sweet-Dew King Painting of the Chosón Dynasty]. In Chiokkye purhwa 地獄系 佛畫 [Hell-Realm Painting], edited by An Kwisuk, Kim Chŏnghŭi, and Yu Mari, 113-180. Vol. 2 of Chsǒnjo purhwa ǔi yŏn'gu 朝鮮朝佛畫究 研 [A Study of Chosǒn Buddhist Paintings]. Sŏngnam: Han'guk chŏngshin munhwa yŏn' guwǒn, 1993.

Yun Ǔnhǔi 윤은희. "Kamnowangdo tosang ŭi hyŏngsǒng munje wa 16, 17 segi Kamnowangdo yŏn'gu: Suryukchae ŭigwejip kwa kwallyǒn hayǒ” 甘露王圖 圖像의 形成 문제와 16,17 세기 甘露王圖 研究: 水陸齋 儀軌集과 관련하여 [The Issue of Iconographic Development of the Sweet-Dew King Painting and the Sweet-Dew King Paintings of the Sixteenth and Seventeenth Centuries: Their Association to the Water-Land Manuals Texts]. Master's thesis, Tongguk University, 2003.

\section{Asian Literature}

Hattori Yoshio 服部良男. “Chōsen lichō butsuga "shoki kanrotei” no sekai: Ōtsu shi Seikyōji shozō Urabonkyō setsusō o yomu” 朝鮮李朝仏画〈初期甘露幀〉の世界: 大津市西敎寺所藏《孟蘭盆経説相》を読む [The World of Early Sweet-Dew Paintings of Chosǒn: Reading the "Tableau of the Ullambana Sütra” Housed in Saikyö-ji]. Ajia yūgaku アジア遊学 29 (2001): 104-115.

\section{English Literature}

Bean, Susan S. “The Arts of Life in Late Chosŏn Dynasty Korea." Arts of Asia 36, no. 3 (May/June 2006): 94-104.

Cambon, Pierre. L'Art Coréen au Musée Guimet. Paris: Reunion des Museés Nationaux, 2001.

Giebel, Rolf W. "Taishō Volumes 18-21." In Esoteric Buddhism and the Tantras in East Asia, edited by Charles D. Orzech, Henrik H. Sørensen, and Richard K. Payne, 27-36. Leiden: Brill, 2011.

Lancaster, Lewis R., and Sung-bae Park. The Korean Buddhist Canon: A Descriptive Catalogue. Berkeley: University of California Press, 1979.

Lye, Hun Y. "Feeding Ghosts: A Study of the Yuqie Yankou Rite." PhD diss., University of Virginia, 2003.

Orzech, Charles D. "Esoteric Buddhism and the Shishi in China." In The Esoteric Buddhist Tradition, edited by Henrik H. Sørensen, 51-72. Copenhagen: The Seminar for Buddhist Studies, 1994.

"Fang Yankou and Pudu: Translation, Metaphor, and Religious Identity." In Daoist Identity: History, Lineage, and Ritual, edited by Livia Kohn and Harold D. Roth, 213-234. Honolulu: University of Hawai'i Press, 2002.

Pak, Taylor. "Shaping the Economy of Salvation: The Gamno Paintings of the Joseon Period (1392-1910)." PhD diss., 
Seoul National University, 2018.

Stevenson, Daniel B. "Buddhist Ritual in the Song." In Song-Liao-Jin-Yuan (962-1368), edited by John Lagerwey and Pierre Marsone, 329-448. Vol. 1 of Modern Chinese Religion. Leiden: Brill, 2015. 


\begin{abstract}
In sixteenth-century Korea, the Buddhist ritual altar for the rites of bestowing food to departed spirits acquired an altarpiece commonly known today as the Sweet-Dew painting (Kamnodo 甘露圖). Owing to the standard three-altar scheme of Chosŏn Buddhist liturgy, the ritualistic implementation of this new Buddhist painting genre thereafter occurred in various offertory services entailing the “food bestowal” (shishik 施食). In the given liturgical framework, this paper especially brings to light the Seven Buddhas represented in the Sweet-Dew painting. It identifies them through examining different assemblages of Buddhas employed in the extant specimens from the Choson period and argues that their functional link to the method of food bestowal is distinctively configured based on the contemporaneous redactions of the FoodBestowal manuals, above all other texts that may potentially have partaken in shaping the Seven Buddhas. The paper first and foremost distinguishes the presence and the liturgical capacity of the SweetDew King as the mainstay of the Seven Buddhas' textual connection. This analysis conclusively refocuses attention on the Food-Bestowal manuals in decoding the iconography of the Sweet-Dew painting.
\end{abstract}




\title{
국문초록
}

\section{朝鮮時代 甘露圖의 七佛 研究}

\author{
박 영 아*
}

'감로도(甘露圖)'는 16세기부터 죽은 영혼에게 음식을 베푸는 '시식(施食)'이라는 의식(儀式)의 일환 으로 제작되기 시작하였다. 새롭게 고안된 회화 장르(genre)인 '감로도'는 조선시대 불교의례의 삼단(三壇) 체계 안에서 하단(下壇)의 불화(佛畫)로서 시식이 동반되는 각종 의례에 사용되는 제단화(祭壇畫)로 기능하였다. 본고는 이와 같은 의례적 맥락에서 '감로도'에 나타나는 '칠불(七佛'을 고찰하였다. 현존하는 74점의 조선시대 '감로도'에 표현된 여러 부처들을 면밀히 검토하여 칠불의 구성을 살펴보았다. 아울러 문헌적 검토를 통하여 각 부처의 명호(名號)와 의례적 역할이 『삼단시식문(三壇施食文)』(1496)을 시작 으로 새롭게 편집되어 16 세기에 등장한 시식의식문(施食儀式文)들에 기반하고 있음을 밝혔다. 특히 칠불의 문헌적 연관성에서 핵심이 되는 감로왕여래(甘露王如來)의 도상(圖像)을 규명하였다. 본고는 '감로도'의 도상을 이해하는 데 있어, 그와 동시기에 출현한 시식의식문과의 직접적인 관계를 제시하고자 한다.

* KAIST(한국과학기술원) 인문사회과학부 